\title{
EFFECT OF DIFFERENT IRRIGATION LEVELS ON PHYSIOLOGICAL PERFORMANCE OF SOME DROUGHT TOLERANT MELON (CUCUMIS MELO L.) GENOTYPES
}

\author{
AKHOUNDNEJAD, Y. ${ }^{*}-$ DASGAN, H. Y. ${ }^{2}$ \\ ${ }^{\text {I}}$ Faculty of Agriculture, Depatment of Horticultur, Sirnak university, 73300 Idil, Sirnak, Turkey \\ ${ }^{2}$ Faculty of Agriculture, Depatment of Horticultur, Cukurova university, Adana, Turkey \\ ${ }^{*}$ Corresponding author \\ e-mail: yakhoundnejad@sirnak.edu.tr; phone: +90-544-864-5435
}

(Received $9^{\text {th }}$ Apr 2019; accepted $19^{\text {th }}$ Jun 2019)

\begin{abstract}
This study was conducted for determining drought tolerance in melon genotypes. In order to reduce the negative effects of the climatic changes on vegetable production, new melon cultivars that are tolerant to water stress are being developing. For this purpose, 9 melon genotypes that were previously found as drought tolerant have been tested in field conditions. In order to determine field performance of the melon genotypes three irrigation treatments with different water levels have been realized; $100 \%$ (control), 50\% and $0 \%$ irrigations. In 50\% and $0 \%$ irrigated plants, the above mentioned parameters have been compared versus their control plants. Some Physiological parameters were investigated. The investigated parameters were: Total fruit yield $(\mathrm{kg} / \mathrm{ha})$, brix in fruit $(\%)$, leaf stoma conductance $\left(\mathrm{mmol} / \mathrm{m}^{2} / \mathrm{s}\right)$, membrane damage on leaf cells $(\%)$, leaf water potential (MPa), leaf osmotic potential (MPa), leaf temperature $\left({ }^{\circ} \mathrm{C}\right), \mathrm{K}$ and $\mathrm{Ca}$ concentrations in leaf $(\%)$, water use efficiency (g/Liter) of the genotypes According to the results melon genotypes were sorted from highest to lowest levels for their stress tolerance.
\end{abstract}

Keywords: irrigation, Cucumis melo, drought, physiological

\section{Introduction}

Abiotic stresses, such as drought, salinity, extreme temperatures, chemical toxicity and oxidative stress are serious threats to agriculture and result in the deterioration of the environment. Abiotic stress is the primary cause of crop loss worldwide, reducing average yields for most major crop plants by more than 50\% (Boyer, 1982; Bray et al., 2000). Drought, salinity, extreme temperatures and oxidative stress are often interconnected, and may induce similar cellular damage. For example, drought and/or salinization are manifested primarily as osmotic stress, resulting in the disruption of homeostasis and ion distribution in the cell (Serrano et al., 1999; Zhu, 2001). Drought and salinity are becoming particularly widespread in many regions, and may cause serious salinization of more than $50 \%$ of all arable lands by the year 2050 (Wang et al., 2003). Abiotic stress leads to a series of morphological, physiological, biochemical and molecular changes that adversely affect plant growth and productivity (Wang et al., 2001). The effect of increased drought stress results in a decrease in germination rate, seedling viability, collective length, root length and shoot length (K1zlgeci, 2017). In this study we studied 9 melon genotypes to appraise the drought stress performance of these genotypes, according to physiological parameters in Adana of Turkey. 


$$
\text { - } 9998 \text { - }
$$

\section{Materials and methods}

As plant material, 9 melon genotypes, gathered from different parts of Turkey country, were used (Table 1 and Fig. 1). These genotypes were previously used in UNDP-MDG-F 1680 project. Study 3. was performed, with the practice, in open field in

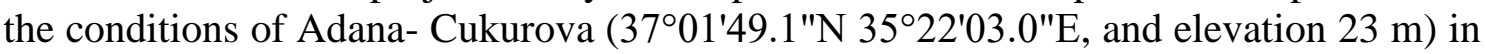
2011 spring-summer. One of the applications (1) is thought as control and completely $100 \%$ irrigation being watered parcels, other one (2) is being watered as much half as of controlled one in other words being 50\% irrigation limited watered parcels, and the last one(3) is being watered as $0 \%$ irrigation of the controlled limited watered parcels.

Table 1. Melon genotypes

\begin{tabular}{c|c}
\hline Genotypes No & Genotypes No \\
\hline Mln-4 & CU-159 \\
Mln-20 & CU-213 \\
Mln-23 & CU-280 \\
Mln27 & CU-311 \\
Mln-28 & \\
\hline
\end{tabular}
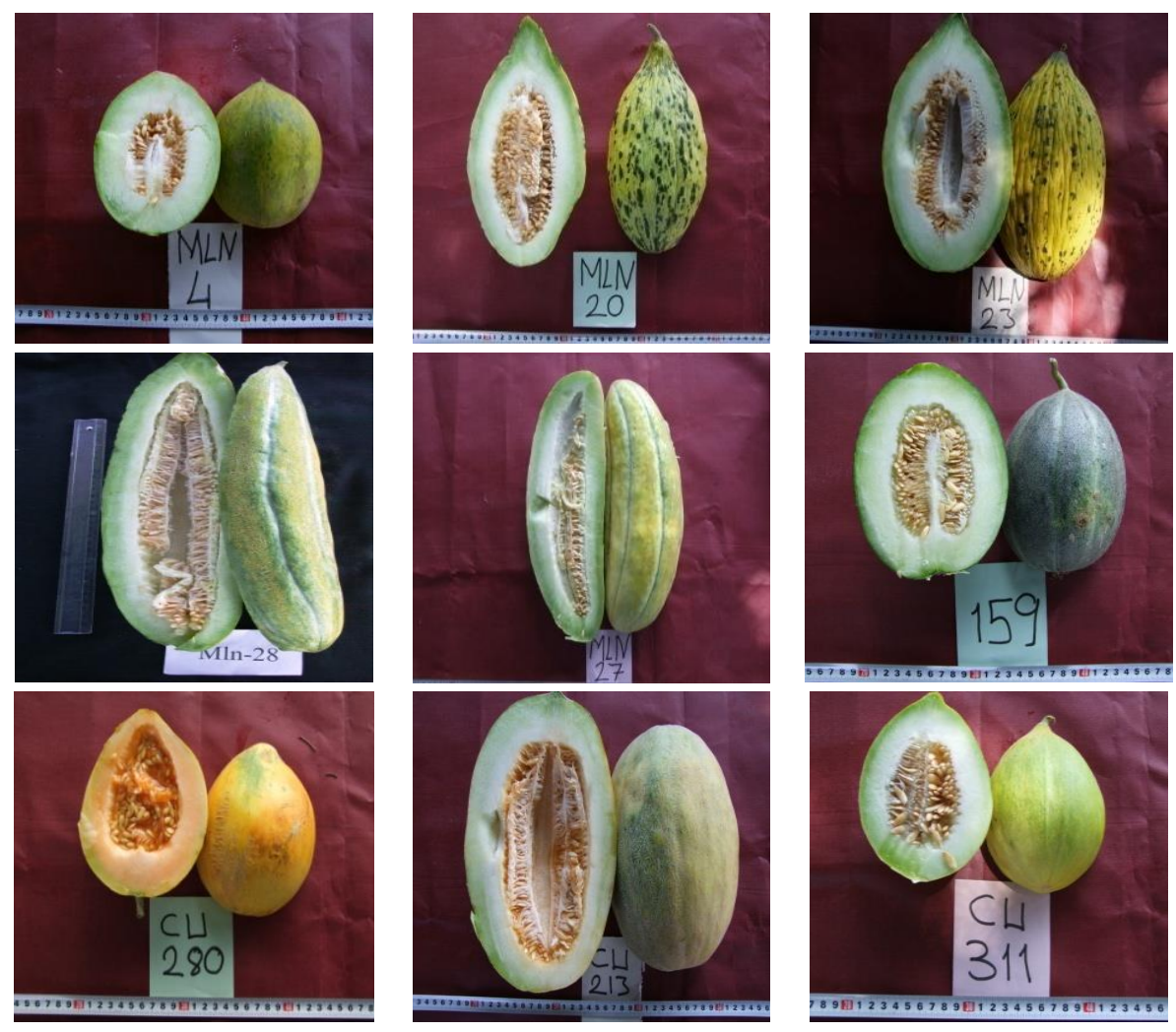

Figure 1. Melon genotypes used in the experiment

The amount of the water, which will be given to the melon plants, was determined according to; the amount of water evapoquantityd from the evaporation pan, the kcp coefficient for melon, test area, and the quantity of vegetation depending on the field of plant growth. Randomized block experiment was established, as 3 recurrence in experimental design and each recurrence being 5 plants. While melons were being planted, 
row space was organized as $180 \mathrm{~cm}$ and the row was organized as $50 \mathrm{~cm}$. The melon seedlings planted on the field were watered in optimum level the same as controlled plants in all 3 applications until they growed for 69 days. The application of water stress of $50 \%$ and $0 \%$ of the control was started on 55 days after they were planted. Different watering stress applied in experiment were done after first blossom. In addition, analyzes were performed after the first fruit formation was seen. The nutrition of the melon plants were done equally in all 3 applications. For this, for a $10000 \mathrm{~m}^{2}$ purely $140 \mathrm{~kg} \mathrm{ha}^{-1} \mathrm{~N}, 95 \mathrm{~kg} \mathrm{ha}^{-1}$ P2O5, $220 \mathrm{~kg} \mathrm{ha}^{-1} \mathrm{~K} 2 \mathrm{O}, 20 \mathrm{~kg} \mathrm{ha}^{-1} \mathrm{MgO}$ and $40 \mathrm{~kg} \mathrm{ha}^{-1} \mathrm{CaO}$; were used (Gunay, 2005). Physical and chemical properties of the orchard soil from depth of $0-30 \mathrm{~cm}$ (Table 2). In the experiment, the monthly minimum, average, rainfall and maximum temperature and humidity values for years 2011 are shown in Figs. 2, 3 and 4, respectively.

Table 2. Physical and chemical properties of the orchard soil from depth of $0-30 \mathrm{~cm}$

\begin{tabular}{c|c|c}
\hline \multicolumn{2}{c|}{ Soil parameters } & Value \\
\hline $\mathrm{pH}$ & -- & 8.1 \\
$\mathrm{EC}$ & $\left(\mathrm{dSm}^{-1}\right)$ & 0.3 \\
$\mathrm{~N}$ & $(\%)$ & 0.19 \\
$\mathrm{P}$ & $\left(\mathrm{kg} \mathrm{P}_{2} \mathrm{O} / \mathrm{ha}\right)$ & 63 \\
$\mathrm{~K}$ & $(\mathrm{~kg} \mathrm{~K} \mathrm{O} / \mathrm{ha})$ & 150.36 \\
$\mathrm{Ca}$ & $(\mathrm{kg} \mathrm{CaO} / \mathrm{ha})$ & 1990.1 \\
$\mathrm{Mg}$ & $(\mathrm{kg} \mathrm{MgO} / \mathrm{ha})$ & 240.3 \\
$\mathrm{Fe}$ & $(\mathrm{ppm})$ & 185 \\
$\mathrm{Mn}$ & $(\mathrm{ppm})$ & 2.82 \\
$\mathrm{Zn}$ & $(\mathrm{ppm})$ & 0.28 \\
$\mathrm{Cu}$ & $(\mathrm{ppm})$ & 0.34 \\
\hline
\end{tabular}

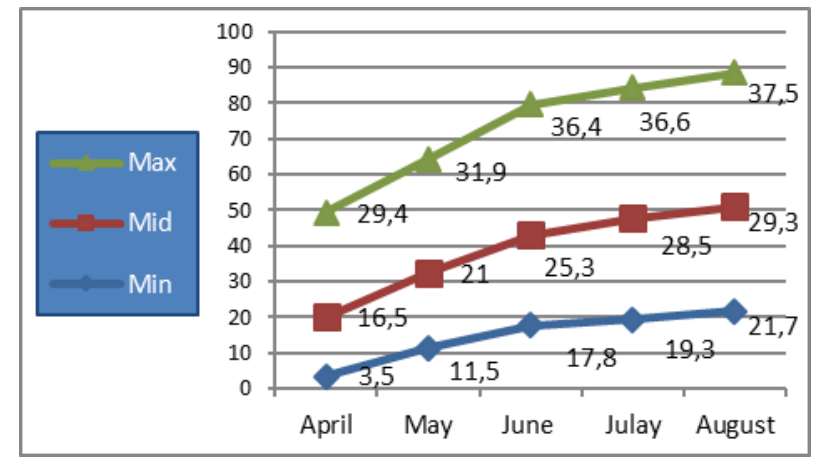

Figure 2. 2011 spring summer period during Max, Mid, Min temperature values $\left({ }^{\circ} \mathrm{C}\right)$

Physiological parameters shown below were examined.

\section{Ca and K concentration in green parts of melon genotype (\%)}

Before the fruit formation of melon plant, the $5^{\text {th }}$ leaf as of the tip was taken and washed in pure water in order to remove dust and similar substances on it. It will be kept in the etuve at $70^{\circ} \mathrm{C}$ for 48 hours. After drying, the leaves will be ground until becoming powdery. 0.200 grams will be weighed and burned in the combustion unit for 6 hours at $550^{\circ} \mathrm{C}$. It was dissolved in 1/3 HCL acid ratio and passed through filter paper. Values were determined with FS 220 Atomic Absorption Spectrophotometer brand device. 


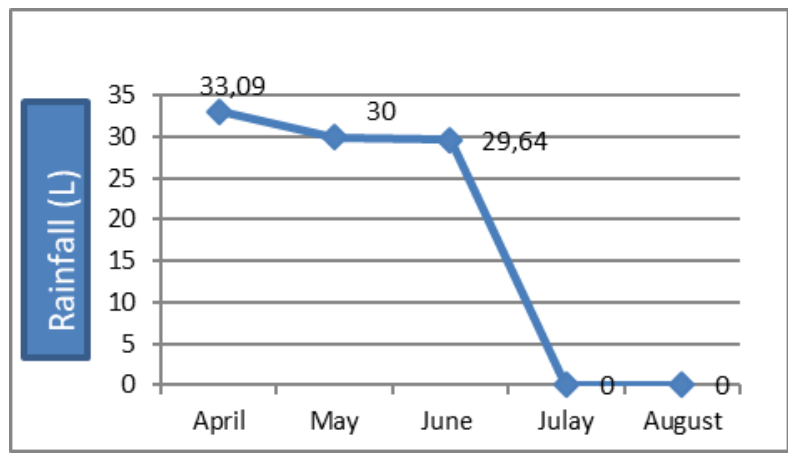

Figure 3. 2011 spring summer period during rainfall $(L)$

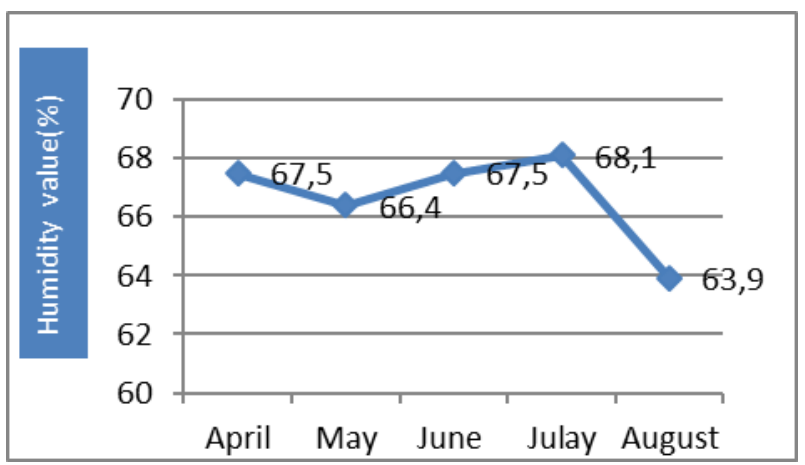

Figure 4. 2011 spring summer period recorded during trial Max, Mid, Min Monthly air relative humidity values (\%)

\section{Membrane damage stages in green parts of melon genotypes (\%)}

In order to determine the damage rate of membrane cells of different melon genotypes, 5 discs $\left(1 \mathrm{~cm}\right.$ diameter metal pipe) were taken from the $4^{\text {th }}$ and $5^{\text {th }}$ leaf of the melon plant down from the tip between the hours of 9: 00-11: 00 and after putting into $20 \mathrm{ml}$ of pure water, they were waited for 4 hours and measured with Ec meter. After measuring, when equilibrated to room temperature after it was kept at $100^{\circ} \mathrm{C}$ for 10 minutes, measured with the EC meter again and calculated with the following formula (Dlugokecka and Kacperska-Palacz, 1978; Fan and Blake, 1994).

The formula of the Membrane Loss Index on the green component is

$$
(\mathrm{Lt}-\mathrm{Lc} / 1-\mathrm{Lc}) \times 100
$$

where

Lt: EC measurement of stress plants before autoclaving /EC measurement after autoclave.

Lc: EC measurement of control plants before autoclaving /EC measurement after autoclave. 


\section{Determination of Leaf Stoma Permeability $\left(\mathrm{mmol} \mathrm{m}^{-2} \mathrm{~s}^{-1}\right)$}

In the melon plant, in order to determine stomata of the leaves as of the $4^{\text {th }}$ part of tip, measurement was done between the hours of 9:00-10:00 in sunny weather by using AP4 model porometer of Delta T Brand Devices.

\section{Determination of Leaf Osmotic Potential (MPa)}

Between the hours of 9:00 and 10:00, after taking samples from the 4 leaves from the tip of experimental melon plant, they were kept at the $-20^{\circ} \mathrm{C}$ and taken to the lab. 1 gram of the green component was mixed with $19 \mathrm{ml}$ of distilled water. After filtering with $0.45 \mu \mathrm{m}$ scale, the liquid samples were taken from $50 \mu \mathrm{l}$ scale samples and measured by Gonatec brand and 030 model osmometer device. Besides, values were calculated as (MPa).

\section{Determination of Leaf Water Potential (MPa)}

In the Soilmoisture brand portable pressure circle, it was measured by taking samples from the $4^{\text {th }}$ leaf from the tip of melon plant between the hours of 9:00-10:00.

\section{Water Use Efficiency $(\mathrm{g} / \mathrm{L})$}

In the experiment, the amount of water given at different levels of stress was recorded at each stage. In addition, the amount of harvest in each stage of the experiment was recorded in each harvest. At the end of the experiment, the water use efficiency of each genotype was calculated by dividing the sum of each genotype by the amount of water spent. Water Usage Efficiency (g/L) formula is calculated by

$$
\text { Total yield (g/ plant) / Amount of water supplied (L / plant) }
$$

The data obtained from the experiment by using JMP packaged software was analyzed statistically and mean was compared according to Tukey test. In the study, changes in physiological parameters recorded and measured in melon genotypes cultivated with $50 \%$ and $0 \%$ irrigation applications, which is water stress applications in two different levels, were calculated as percentages compare to non-stress control plants (\% 100 application). In total 10 parameters, the mean of the changes according to the control of both water stress applications was taken. A special method "weighed classification method", was developed for this study. Accordingly, scores were assigned to each of the selected parameters according to their significance level (Table 3), and the averages of the changes were multiplied by the score gained the parameters in the weighed classification system.

After parameters were multiplied by it'sown multiplier, all parameters were added. According to the total score obtained, 9 melon genotypes were arranged as from the best performing to the least performing. Watering time was carried out as once a week. The amount of irrigation water to be applied to plants according to the evaporation values read daily from the evaporation tank (Class Apan) was calculated by means of the following equality. In the study, "Full Plastic" drip irrigation laterals, placed with $50 \mathrm{~cm}$ spaces with a diameter of $16 \mathrm{~mm}$ and a flow rate of $2 \mathrm{~L} / \mathrm{h}$ were used in the drip irrigation system. The amount of irrigation water given to the plants in the experiment was determined by the following formula. Water usage efficiency of melon genotypes is shown below (Table 4). 


$$
\mathrm{IR}=\mathrm{A} * \mathrm{E} \text { pan } * \mathrm{kcp} * \mathrm{P}
$$

where

IR: Amount of water applied $\left(\mathrm{m}^{3}\right)$.

A: Size of the parcel (ha).

E pan: Evaporation amount $(\mathrm{mm})$.

kcp: Coefficient of plant (melon) (0.80).

P-cover: Flora \%.

P-cover: Plant Crown Width $(\mathrm{cm}) /$ Row spacing $(\mathrm{cm})$.

Table 3. Score according to significant level of melon experiment

\begin{tabular}{c|c}
\hline Parameters & Point \\
\hline Total fruit yield & 30 \\
leaf osmotic potential & 6 \\
leaf stoma conductance & 12 \\
leaf water potential & 9 \\
leaf temperature & 7 \\
Membrane damage on leaf cells & 8 \\
Ca concentrations in leaf & 6 \\
K concentrations in leaf & 6 \\
Brix in fruit & 7 \\
Water use efficiency & 9 \\
Total & 100 \\
\hline
\end{tabular}

Table 4. Water use efficiency of the melon genotypes ( $\mathrm{g} /$ Liter)

\begin{tabular}{c|c|c|c|c}
\hline \multirow{2}{*}{ Application } & $\begin{array}{c}\text { Stress before } \\
(\mathbf{0 4 . 0 4 . 2 0 1 1}-\mathbf{2 6 . 0 5 . 2 0 1 1 )}\end{array}$ & $\begin{array}{c}\text { Stress after } \\
\mathbf{( 0 8 . 0 6 . 2 0 1 1 - 2 0 . 0 7 . 2 0 1 1 )}\end{array}$ & Rain* & Total water \\
\hline $100 \%$ & $31.2 \mathrm{~L}$ & $50.57 \mathrm{~L}$ & $55.61 \mathrm{~L}$ & $137.38 \mathrm{~L}$ \\
$50 \%$ & $31.2 \mathrm{~L}$ & $25.28 \mathrm{~L}$ & $55.61 \mathrm{~L}$ & $112.09 \mathrm{~L}$ \\
$0 \%$ & $31.2 \mathrm{~L}$ & - & $55.61 \mathrm{~L}$ & $86.81 \mathrm{~L}$ \\
\hline
\end{tabular}

*Rainfall date: (01.04.2011-30.04.2011) $33.06 \mathrm{~L}, \quad(01.05 .2011-31.05 .2011) \quad 30 \mathrm{~L}, \quad(01.06 .2011-$ 31.06.2011) 29.64L

\section{Results and discussion}

The results of ANOVA for physiological properties are in Table 5. Statistical data analysis for the leaf stoma conductance, leaf water potential, $\mathrm{Ca}, \mathrm{K}$ concentrations in leaf, Membrane damage on leaf cells, Water use efficiency and Total fruit yield the analysis of variance, stress and genotypes $\mathrm{x}$ stress interactions were found significant but the genotypes were insignificant for leaf stoma conductance, Brix in fruit and leaf temperature. The average value of leaf stoma conductance under drought stress $50 \%$ and $0 \%$ irrigation of melon genotypes tested has been $140.39,83.6$, respectively and the mean of control plants has been 107.74 .

Decrease $50 \%$ and $0 \%$ irrigation indices has occurred as $46.22 \%,-27,86 \%$, respectively according to control of melon genotypes under drought stress (Table 6). The average value of leaf temperature under drought stress $50 \%$ and $0 \%$ irrigation of melon genotypes tested has been $27.34^{\circ} \mathrm{C}, 31.28^{\circ} \mathrm{C}$, respectively and the mean of control plants has been $29.80^{\circ} \mathrm{C}$. Increase $50 \%$ and $0 \%$ irrigation indices has occurred as $3.83 \%, 5.86 \%$, respectively according to control of melon genotypes under drought stress (Table 7). Turner et al. (1998) reported that as the osmotic potential decreases, stoma conductivity decreases in sorghum 


$$
-10003 \text { - }
$$

and sunflowers. Similar results were obtained in chickpea (Mafakheri, 2010), sugar beet (Dadkhah, 2010), tomato (Zhou et al., 2017) and hazelnut (Silva et al., 2011). During drought, leaves are exposed to both heat and water deficiency stress (Clarke et al., 1993).

Table 5. Analysis of variance and physiological properties of melon genotypes

\begin{tabular}{c|c|c|c|c|c|c|c|c|c|c}
\hline $\begin{array}{c}\text { Analysis of } \\
\text { variance }\end{array}$ & $\begin{array}{c}\text { Total } \\
\text { fruit } \\
\text { yield }\end{array}$ & $\begin{array}{c}\text { Leaf } \\
\text { osmotic } \\
\text { potential }\end{array}$ & $\begin{array}{c}\text { Leaf stoma } \\
\text { conductance }\end{array}$ & $\begin{array}{c}\text { Leaf } \\
\text { water } \\
\text { potential }\end{array}$ & $\begin{array}{c}\text { Leaf } \\
\text { temperature }\end{array}$ & $\begin{array}{c}\text { Membrane } \\
\text { damage on } \\
\text { leaf cells }\end{array}$ & $\mathrm{Ca}$ & $\mathrm{K}$ & $\begin{array}{c}\text { Brix in } \\
\text { fruit }\end{array}$ & $\begin{array}{c}\text { Water use } \\
\text { efficiency }\end{array}$ \\
\hline Stress(s) & $* *$ & $* *$ & $* *$ & $*$ & $\mathrm{~ns}$ & $* *$ & $* *$ & $*$ & $\mathrm{~ns}$ & $* *$ \\
Genotypes(G) & $* *$ & $\mathrm{~ns}$ & $* *$ & $\mathrm{~ns}$ & $\mathrm{~ns}$ & $*$ & $* *$ & $*$ & $\mathrm{~ns}$ & $* *$ \\
$\mathrm{~S} * \mathrm{G}$ & $* *$ & $\mathrm{~ns}$ & $*$ & $*$ & $\mathrm{~ns}$ & $*$ & $* *$ & $*$ & $\mathrm{~ns}$ & $* *$ \\
$\mathrm{CV}(\%)$ & 4.25 & -6.02 & 4.34 & -8.93 & 1.52 & 4.32 & 8.38 & 8.36 & 3.01 & 3.37 \\
\hline
\end{tabular}

$\mathrm{ns}=$ not significantly, $(*)$ and $(* *)$ are significant at 0.05 and 0.01 , respectively

Table 6. In the applications of melon genotypes quantities in different 50\% and $0 \%$ irrigation under the normal condition and drought stress condition; leaf stoma conductance quantity of (\%) change by to control

\begin{tabular}{|c|c|c|c|c|c|}
\hline Genotypes No & $\begin{array}{c}100 \% \text { irrigation } \\
(\mathrm{mmol} / \mathrm{m} 2 / \mathrm{s})\end{array}$ & $\begin{array}{c}50 \% \text { irrigation } \\
(\mathrm{mmol} / \mathrm{m} 2 / \mathrm{s})\end{array}$ & $\begin{array}{c}\text { 0\% irrigation } \\
(\mathrm{mmol} / \mathrm{m} 2 / \mathrm{s})\end{array}$ & $\begin{array}{l}50 \% \text { irrigation } \\
\text { change by to } \\
\text { control }(\%)\end{array}$ & $\begin{array}{l}\text { o\% irrigation } \\
\text { change by to } \\
\text { control }(\%)\end{array}$ \\
\hline Mln-4 & $257 \mathrm{a}$ & $105 \mathrm{de}$ & $68.68 \mathrm{c}$ & -59.14 & -89.04 \\
\hline Mln-20 & $66 f$ & $149.3 b$ & $94.3 b$ & 126.21 & -36.84 \\
\hline Mln-23 & $69.67 f$ & $96 \mathrm{e}$ & $88.3 \mathrm{bc}$ & 37.79 & -8.02 \\
\hline Mln-27 & $151 b$ & $349 \mathrm{ba}$ & $38.3 \mathrm{e}$ & 131.32 & -19.43 \\
\hline Mln-28 & $59.33 \mathrm{~g}$ & $78.67 f$ & $84.6 \mathrm{~d}$ & 32.60 & -12.80 \\
\hline $\mathrm{Cu}-159$ & $97.67 d$ & $118 \mathrm{c}$ & $107 \mathrm{a}$ & 20.81 & -9.32 \\
\hline CU-213 & $123 \mathrm{c}$ & $144.3 b$ & $92 b$ & 17.32 & -36.24 \\
\hline $\mathrm{Cu}-280$ & $65 f g$ & $111 \mathrm{~cd}$ & $73.3 \mathrm{~d}$ & 70.77 & -33.96 \\
\hline CU-311 & $81 \mathrm{e}$ & $112 \mathrm{~cd}$ & $106.3 \mathrm{a}$ & 38.27 & -5.09 \\
\hline Mean & 107.74 & 140.39 & 83.6 & 46.22 & -27.86 \\
\hline $\operatorname{LSD}_{0.05}$ & 6.02 & 12.21 & 6.95 & - & - \\
\hline
\end{tabular}

Table 7. In the applications of melon genotypes quantities in different $50 \%$ and $0 \%$ irrigation under the normal condition and drought stress condition; leaf temperature quantity of (\%) change by to control

\begin{tabular}{c|c|c|c|c|c}
\hline Genotypes No & $\begin{array}{c}\mathbf{1 0 0 \%} \text { irrigation } \\
\left({ }^{\circ} \mathbf{C}\right)\end{array}$ & $\begin{array}{c}\mathbf{5 0 \%} \text { irrigation } \\
\left({ }^{\circ} \mathbf{C}\right)\end{array}$ & $\begin{array}{c}\mathbf{0 \%} \text { irrigation } \\
\left({ }^{\circ} \mathbf{C}\right)\end{array}$ & $\begin{array}{c}\mathbf{5 0 \%} \text { irrigation } \\
\text { change by to } \\
\text { control }(\boldsymbol{\%})\end{array}$ & $\begin{array}{c}\mathbf{0 \%} \text { irrigation } \\
\text { change by to } \\
\text { control }(\boldsymbol{\%})\end{array}$ \\
\hline Mln-4 & $26.25 \mathrm{~g}$ & $32.31 \mathrm{ab}$ & $33.22 \mathrm{a}$ & 23.09 & 26.55 \\
Mln-20 & $33.03 \mathrm{a}$ & $28.90 \mathrm{gh}$ & $30.12 \mathrm{~d}$ & -12.50 & -8.81 \\
Mln-23 & $28.20 \mathrm{ef}$ & $31.13 \mathrm{~cd}$ & $32.65 \mathrm{a}$ & 10.39 & 15.78 \\
Mln-27 & $31.74 \mathrm{~b}$ & $29.70 \mathrm{fe}$ & $29.29 \mathrm{~d}$ & -6.43 & -7.72 \\
Mln-28 & $30.48 \mathrm{c}$ & $28.43 \mathrm{~h}$ & $27.74 \mathrm{e}$ & -6.73 & -8.99 \\
$\mathrm{Cu}-159$ & $28.94 \mathrm{de}$ & $31.80 \mathrm{bc}$ & $32.45 \mathrm{ab}$ & 9.88 & 12.13 \\
$\mathrm{CU}-213$ & $27.27 \mathrm{f}$ & $33.01 \mathrm{a}$ & $33.14 \mathrm{a}$ & 21.05 & 21.53 \\
$\mathrm{Cu}-280$ & $29.47 \mathrm{~d}$ & $30.66 \mathrm{de}$ & $31.13 \mathrm{c}$ & 4.04 & 5.63 \\
$\mathrm{CU}-311$ & $32.89 \mathrm{a}$ & $30.16 \mathrm{ef}$ & $31.79 \mathrm{bc}$ & -8.30 & -3.34 \\
\hline Mean & 29.80 & 27.34 & 31.28 & 3.83 & 5.86 \\
LSD 0.05 & 0.82 & 0.81 & 0.77 & - & - \\
\hline
\end{tabular}


As the leaf temperature increased, a decrease in the transpiration rates of the leaves was observed. All of the melon genotypes were increased leaf temperature under salt and drought stress. The best performers in terms of leaf stoma conductance have been selected by taking into account the $\%$ change quantities $50 \%$ and $0 \%$ irrigation of the melon genotypes in the experiment in comparison to their control in drought stress application. These genotypes are respectively; Mln-27 (131.32\%) and Cu311 (-5.09\%), and the most affected $50 \%$ and $0 \%$ irrigation of melon genotypes from the percentage change in the drought stress compared to control have been Mln-4(-70\%) and Mln-4 ($89.04 \%$ ), respectively (Table 6). The best performers in terms of leaf temperature have been selected by taking into account the $\%$ change quantities $50 \%$ and $0 \%$ irrigation of the melon genotypes in the experiment in comparison to their control in drought stress application. These genotypes are respectively; Mln-20 (-12.50\%) and Mln-20 (-8.81\%), and the most affected $50 \%$ and $0 \%$ irrigation of melon genotypes from the percentage change in the drought stress compared to control have been Mln4 (23.09\%) and Mln4 $(26.55 \%)$, respectively (Table 7$)$. Leaf temperature of all melon genotypes increased under drought stress. Lack of water and salinity cause stoma closure, a reduced transpiration rate, and high canopy leaf temperature (Halim et al., 1990). During drought, leaves are exposed to both heat and water deficiency stress (Clarke et al., 1993). As a result of the decrease in the transpiration rates of the leaves, the leaf temperature increases. All melon genotypes increased leaf temperature under salt and drought stress. Mohammadian et al. (2001) asserted that sugar beet becomes fading in the conditions of drought in response to the lack of water and tend to spread to the soil and thus increased the effective area exposed to the sun, so the decreased transpiration rates of these leaves increase the temperature of the leaf. Azevedo et al. (2004) reported that leaf temperature increased with salinity.

The average value of leaf water potential, osmotic potentialunder drought stress $50 \%$ and $0 \%$ irrigation of melon genotypes tested has been $-0.32,-0.32$ in $50 \%$ irrigation and $-0.27,-0.26$ in $0 \%$ irrigation the mean of control plants has been $-0.54,-0.16$, respectively (Tables 8, 9). It may cause to holding relatively large volumes of protoplasts in the inhibition of photosynthesis under low osmotic potential (Matthews and Boyer, 1984; Chaves et al., 2002; Grzesiak et al., 2006). Leaf water potential and osmotic potential of all melon genotypes decreased under salt and drought stress.

Table 8. In the applications of melon genotypes quantities in different 50\% and $0 \%$ irrigation under the normal condition and drought stress condition; leaf water potential quantity of (\%) change by to control

\begin{tabular}{|c|c|c|c|c|c|}
\hline Genotypes No & $\begin{array}{c}100 \% \text { irrigation } \\
\text { (MPa) }\end{array}$ & $\begin{array}{l}50 \% \text { irrigation } \\
(\mathrm{MPa})\end{array}$ & $\begin{array}{c}\text { 0\% irrigation } \\
(\mathrm{MPa})\end{array}$ & $\begin{array}{l}50 \% \text { irrigation } \\
\text { change by to } \\
\text { control }(\%)\end{array}$ & $\begin{array}{c}\text { 0\% irrigation } \\
\text { change by to } \\
\text { control }(\%)\end{array}$ \\
\hline Mln-4 & $-0.61 \mathrm{de}$ & $-0.26 c$ & $-0.14 b$ & $\begin{array}{l}-57.38 \\
\end{array}$ & -77.05 \\
\hline Mln-20 & $-0.68 \mathrm{e}$ & $-0.45 \mathrm{e}$ & $-0.45 f$ & -33.82 & -23.17 \\
\hline Mln-23 & $-0.47 a b$ & $-0.33 d$ & $-0.24 c$ & -29.79 & -48.94 \\
\hline Mln-27 & $-0.59 \mathrm{~cd}$ & $-0.53 f$ & $-0.58 \mathrm{e}$ & -10.17 & -14.71 \\
\hline Mln-28 & $-0.53 b c$ & $-0.43 e$ & $-0.35 d$ & -18.87 & -33.96 \\
\hline $\mathrm{Cu}-159$ & $-0.44 \mathrm{a}$ & $-0.18 b$ & $-0.11 a b$ & -59.09 & -75.00 \\
\hline CU-213 & $-0.42 \mathrm{a}$ & $-0.12 \mathrm{a}$ & $-0.09 a$ & -79.31 & -84.48 \\
\hline $\mathrm{Cu}-280$ & $-0.58 \mathrm{~cd}$ & $-0.16 a b$ & $-0.10 a b$ & -61.90 & -76.19 \\
\hline CU-311 & $-0.54 b d$ & $-0.43 \mathrm{e}$ & $-0.33 \mathrm{~d}$ & -20.37 & -38.89 \\
\hline Mean & -0.54 & -0.32 & -0.27 & -41.19 & -52.49 \\
\hline $\operatorname{LSD}_{0.05}$ & 0.082 & 0.055 & 0.037 & - & - \\
\hline
\end{tabular}


However, resistant genotypes showed high water potential in both stress conditions. Levitt (1972), Ashraf and Oleary (1996), Anyia and Herzog (2004), Xu and Zhou (2008), Fahad et al. (2017) and Echevarri-Zomeno et al. (2009) suggested that leaf water potential may differ between durable and sensitive cultures of different crops. In addition, drought tolerant plants are expected to have a much lower osmotic potential than those that are susceptible to drought when exposed (Ashraf and Oleary, 1996). Considering the $50 \%$ and $0 \%$ irrigation in the experiment, the best genotypes showing the best response in terms of leaf water potentialwere selected. These genotypes are respectively; Mln 27 (-10.17\%) and Mln27 (-14.71\%), and the most affected 50\% and $0 \%$ irrigation of melon genotypes from the percentage change in the drought stress compared to control have been $\mathrm{Cu} 213(-79.31 \%)$ and $\mathrm{Cu} 213(-84.48 \%)$, respectively (Table 8). Considering the $50 \%$ and $0 \%$ irrigation in the experiment, the best genotypes showing the best response in terms of osmotic potential were selected. These genotypes are respectively; Mln27 (11.65\%) and Mln27 (12.5\%), and the most affected 50\% and $0 \%$ irrigation of melon genotypes from the percentage change in the drought stress compared to control have been Mln4 (-17.24\%) and CU213 (35.85\%), respectively (Table 9).

Table 9. In the applications of melon genotypes quantities in different $50 \%$ and $0 \%$ irrigation under the normal condition and drought stress condition; leaf osmotic potential quantity of (\%) change by to control

\begin{tabular}{c|c|c|c|c|c}
\hline Genotypes No & $\begin{array}{c}\mathbf{1 0 0 \%} \text { irrigation } \\
\text { (MPa) }\end{array}$ & $\begin{array}{c}\mathbf{5 0 \%} \text { irrigation } \\
\text { (MPa) }\end{array}$ & $\begin{array}{c}\text { 0\% irrigation } \\
\text { (MPa) }\end{array}$ & $\begin{array}{c}\mathbf{5 0 \%} \text { irrigation } \\
\text { change by to } \\
\text { control (\%) }\end{array}$ & $\begin{array}{c}\text { 0\% irrigation } \\
\text { change by to } \\
\text { control (\%) }\end{array}$ \\
\hline Mln-4 & $-0.1490 \mathrm{a}$ & -0.12 & $-0.14 \mathrm{a}$ & -17.24 & -6.42 \\
Mln-20 & $-0.1520 \mathrm{a}$ & -0.45 & $-0.20 \mathrm{c}$ & 196.05 & 31.58 \\
Mln-23 & $-0.1776 \mathrm{~b}$ & -0.32 & $-0.23 \mathrm{~d}$ & 80.18 & 29.50 \\
Mln-27 & $-0.1433 \mathrm{a}$ & -0.16 & $-0.18 \mathrm{~b}$ & 11.65 & 12.5 \\
Mln-28 & $-0.1496 \mathrm{a}$ & -0.43 & $-0.34 \mathrm{ef}$ & 187.43 & 128.19 \\
Cu-159 & $-0.1640 \mathrm{ab}$ & -0.18 & $-0.24 \mathrm{~d}$ & 9.76 & 46.34 \\
CU-213 & $-0.1526 \mathrm{a}$ & -0.53 & $-0.34 \mathrm{ef}$ & 247.31 & -35.85 \\
Cu-280 & $-0.1450 \mathrm{a}$ & -0.26 & $-0.34 \mathrm{f}$ & 74.50 & 134.48 \\
CU-311 & $-0.1776 \mathrm{~b}$ & -0.43 & $-0.33 \mathrm{e}$ & 142.12 & 85.81 \\
\hline Mean & -0.16 & -0.32 & -0.26 & 103.53 & 47.35 \\
LSD 0.05 & 0.02 & $\mathrm{~ns}$ & 0.01 & - & - \\
\hline
\end{tabular}

ns = not significantly

The average value of $\mathrm{Ca}$ concentrations in leaf under drought stress $50 \%$ and $0 \%$ irrigation of melon genotypes tested has been 4.03 and 3.22, respectively and the mean of control plants has been 5.13. Decrease 50\% and $0 \%$ irrigation indices have occurred as $17.77 \%, 35.37 \%$ respectively according to control of melon genotypes under drought stress (Table 10). The average value of $\mathrm{K}$ concentrations in leaf under drought stress $50 \%$ and $0 \%$ irrigation of melon genotypes tested has been 4.03 and 3.22, respectively and the mean of control plants has been 5.13. Decrease 50\% and $0 \%$ irrigation indices have occurred as $19.63 \%, 30.05 \%$, respectively according to control of melon genotypes under drought stress (Table 11). In the present experiment, calcium (Ca) levels in the leaves were significantly lower in the water-stressed plants and supplemented potassium (K) enhanced leaf $\mathrm{Ca}$. In this study, It is clearly seen that under $0 \%$ drought stress, calcium concentration is significantly lower than potassium concentration (Tables 10, 11). Similar results were reported in Pearlmillet (Ashraf et al., 2002). Calcium plays a 
vital role in maintaining membrane stability and permeability (Mengel and Kirkby, 1987). Higher Ca concentrations in plant tissues can also help with better crop health with improved yields in stress conditions (Cachorro et al., 1994).

Considering the $50 \%$ and $0 \%$ irrigation in the experiment, the best genotypes showing the best response in terms $\mathrm{Ca}$ and $\mathrm{K}$ concentrations in leaf were selected. This genotypeis respectively; Mln 28 and the most affected 50\% and 0\% irrigation of melon genotypes from the percentage change in the drought stress compared to control have been $\mathrm{mln} 4$ and $\mathrm{Cu} 213$, respectively (Tables 10, 11).

Table 10. In the applications of melon genotypes quantities in different $50 \%$ and $0 \%$ irrigation under the normal condition and drought stress condition; Ca concentrations in leaf quantity of $(\%)$ change by to control

\begin{tabular}{c|c|c|c|c|c}
\hline Genotypes No & $\begin{array}{c}\mathbf{1 0 0 \%} \text { irrigation } \\
(\%)\end{array}$ & $\begin{array}{c}\mathbf{5 0 \%} \text { irrigation } \\
(\boldsymbol{\%})\end{array}$ & $\begin{array}{c}\mathbf{0 \%} \text { irrigation } \\
\mathbf{( \% )}\end{array}$ & $\begin{array}{c}\mathbf{5 0 \%} \text { irrigation } \\
\text { change by to } \\
\text { control } \mathbf{( \% )}\end{array}$ & $\begin{array}{c}\text { 0\% irrigation } \\
\text { change by to } \\
\text { control }(\boldsymbol{\%})\end{array}$ \\
\hline Mln-4 & $7.56 \mathrm{a}$ & $2.81 \mathrm{e}$ & $1.49 \mathrm{~d}$ & -62.83 & -80.29 \\
Mln-20 & $7.50 \mathrm{a}$ & $7.19 \mathrm{a}$ & $7.53 \mathrm{a}$ & -4.13 & 0.40 \\
Mln-23 & $4.55 \mathrm{~d}$ & $2.22 \mathrm{f}$ & $1.54 \mathrm{c}$ & -51.21 & -66.15 \\
Mln-27 & $3.44 \mathrm{e}$ & $3.76 \mathrm{~d}$ & $3.45 \mathrm{c}$ & 9.30 & 0.29 \\
Mln-28 & $3.49 \mathrm{c}$ & $4.47 \mathrm{c}$ & $3.79 \mathrm{c}$ & 28.08 & 8.60 \\
Cu-159 & $3.01 \mathrm{f}$ & $2.22 \mathrm{f}$ & $1.13 \mathrm{~d}$ & -26.25 & -62.46 \\
CU-213 & $5.42 \mathrm{c}$ & $2.79 \mathrm{e}$ & $0.49 \mathrm{e}$ & -48.52 & -90.96 \\
Cu-280 & $5.79 \mathrm{~b}$ & $4.29 \mathrm{~cd}$ & $3.86 \mathrm{c}$ & -25.91 & -33.33 \\
CU-311 & $5.39 \mathrm{c}$ & $6.55 \mathrm{~b}$ & $5.69 \mathrm{~b}$ & 21.52 & 5.57 \\
\hline Mean & 5.13 & 4.03 & 3.22 & -17.77 & -35.37 \\
LSD 0.05 & 0.22 & 0.24 & 0.49 & - & - \\
\hline
\end{tabular}

Table 11. In the applications of melon genotypes quantities in different $50 \%$ and $0 \%$ irrigation under the normal condition and drought stress condition; $K$ concentrations in leaf quantity of (\%) change by to control

\begin{tabular}{c|c|c|c|c|c}
\hline Genotypes No & $\begin{array}{c}\mathbf{1 0 0 \%} \text { irrigation } \\
(\boldsymbol{\%})\end{array}$ & $\begin{array}{c}\mathbf{5 0 \%} \text { irrigation } \\
(\boldsymbol{\%})\end{array}$ & $\begin{array}{c}\mathbf{0 \%} \text { irrigation } \\
\mathbf{( \% )}\end{array}$ & $\begin{array}{c}\mathbf{5 0 \%} \text { irrigation } \\
\text { change by to } \\
\text { control (\%) }\end{array}$ & $\begin{array}{c}\text { 0\% irrigation } \\
\text { change by to } \\
\text { control (\%) }\end{array}$ \\
\hline Mln-4 & $3.56 \mathrm{a}$ & $1.21 \mathrm{~cd}$ & $0.65 \mathrm{~b}$ & -66.01 & -81.74 \\
Mln-20 & $2.84 \mathrm{c}$ & $2.66 \mathrm{~b}$ & $2.45 \mathrm{~b}$ & -6.34 & -13.73 \\
Mln-23 & $2.49 \mathrm{de}$ & $1.45 \mathrm{c}$ & $1.05 \mathrm{c}$ & -41.77 & -57.83 \\
Mln-27 & $3.50 \mathrm{a}$ & $3.67 \mathrm{a}$ & $3.45 \mathrm{a}$ & 4.86 & -1.43 \\
Mln-28 & $2.57 \mathrm{~d}$ & $3.87 \mathrm{a}$ & $3.17 \mathrm{a}$ & 50.58 & 23.35 \\
Cu-159 & $2.42 \mathrm{de}$ & $0.77 \mathrm{de}$ & $0.58 \mathrm{~d}$ & -68.18 & -76.03 \\
CU-213 & $3.35 \mathrm{ab}$ & $0.77 \mathrm{e}$ & $0.39 \mathrm{~d}$ & -77.01 & -88.36 \\
Cu-280 & $2.29 \mathrm{e}$ & $2.68 \mathrm{~b}$ & $2.75 \mathrm{~b}$ & 17.03 & 20.09 \\
CU-311 & $3.24 \mathrm{~b}$ & $3.57 \mathrm{a}$ & $3.41 \mathrm{a}$ & 10.19 & 5.25 \\
\hline Mean & 2.918 & 2.29 & 1.989 & -19.63 & -30.05 \\
LSD 0.05 & 0.24 & 0.45 & 0.33 & - & - \\
\hline
\end{tabular}

Knight et al. (1997) showed that osmotic stress increases the cytosolic free calcium in Arabidopsis seedlings and these changes in $\mathrm{Ca}^{2+}$ levels can mediate the expression of drought-induced genes with protective functions. Potassium nutrient can management has the potential to minimum the influences of drought stress in cotton (Zahoor et al., 2016) and Similar study (Kusvuran and Dasgan, 2011). Askari et al. (2017) rapored that drought stress highest effect on reducing content of chlorophyll index and concentration 
of $\mathrm{N}$ and $\mathrm{P}$ nutrition element in leafage, while concentrations of $\mathrm{K}, \mathrm{Zn}, \mathrm{Fe}, \mathrm{Cu}$ and $\mathrm{Na}$ raised with drought stress. The lower tolerability of plants with K-deficiency can be attributed to the role of $\mathrm{K}$ in stoma regulation, which is the main mechanism that controls the water balance in plants. This may also be due to the role of $\mathrm{K}$ as the major osmoticum in the vacuole, even maintain a high tissue water potential in severe drought conditions.

The average value of membrane damage on leaf cells under drought stress $50 \%$ and $0 \%$ irrigation of melon genotypes tested has been 7.23 and 8.00, respectively (Table 12). The cell membrane is one of the main cellular targets common to different stresses (Levitt, 1972). The extent of its damage is commonly used as a measure of tolerance to various stresses in plants such as freezing heat (Dexter, 1956), drought (Blum and Ebercon, 1981; Tiwari et al., 2016) and salt (Leopold and Willing, 1983). Bewley (1979) reviewed drying tolerance in high plants and concluded that the critical properties of desiccant tolerance depend on their ability to limit membrane damage during water stress and to regain membrane integrity and membrane-related activities on rehydration.

Table 12. In the applications of melon genotypes quantities in different $50 \%$ and $0 \%$ irrigation under the normal condition and drought stress condition; membrane damage on leaf cells quantity of (\%) change by to control

\begin{tabular}{c|c|c}
\hline Genotypes No & $\mathbf{5 0 \%}$ Irrigation & 0\% Irrigation \\
\hline Mln-4 & $8.20 \mathrm{~b}$ & $5.58 \mathrm{f}$ \\
Mln-20 & $4.72 \mathrm{f}$ & $5.48 \mathrm{f}$ \\
Mln-23 & $6.74 \mathrm{~d}$ & $5.34 \mathrm{f}$ \\
Mln-27 & $7.53 \mathrm{c}$ & $11.56 \mathrm{~b}$ \\
Mln-28 & $9.06 \mathrm{a}$ & $13.07 \mathrm{a}$ \\
Cu-159 & $8.14 \mathrm{bc}$ & $8.40 \mathrm{~d}$ \\
CU-213 & $8.52 \mathrm{ab}$ & $5.80 \mathrm{f}$ \\
Cu-280 & $6.63 \mathrm{~d}$ & $7.47 \mathrm{e}$ \\
CU-311 & $5.54 \mathrm{e}$ & $9.32 \mathrm{c}$ \\
\hline Mean & 7.23 & 8.00 \\
LSD 0.05 & 0.63 & 0.49 \\
\hline
\end{tabular}

The average Brix value in the fruit under drought stress was $50 \%$ and $0 \%$ irrigation of the tested melon genotypes was $6.74,8.62$ respectively, and the control plants average was 6.28. According to control, $50 \%$ and $0 \%$ irrigation indexes of melon genotypes under drought stress, were $10.75 \%$ and $47.91 \%$, respectively (Table 13). The Brix value was found higher forthe melon by less irrigation (Shmueli and Golsberg, 1971; Bhella, 1985; Lester et al., 1994). In contrast to the other observed parameters, the linear regression test has a value of 0.60 and $0.32 \mathrm{r} 2$ for the sub-surface drip irrigation system. Brix and r2 values are better explained as 0.27 and 0.4 for the surface drip irrigation system. However, Fabeiro et al. (2002) detected in their conducted study that the value of Birx decreases as irrigation increases.

Considering the $50 \%$ and $0 \%$ irrigation in the experiment, the best genotypes showing the best response in terms of Brix of fruit were selected. These genotypes are respectively; Mln (32.39\%) and Mln (125.51\%), and the most affected 50\% and 0\% irrigation of melon genotypes from the percentage change in the drought stress compared to control have been $\mathrm{Cu} 213(-15.71 \%)$ and $\mathrm{Cu} 213(-12.42 \%)$, respectively (Table 13). 
Table 13. In the applications of melon genotypes quantities in different $50 \%$ and $0 \%$ irrigation under the normal condition and drought stress condition; brix in fruit quantity of (\%) change by to control

\begin{tabular}{|c|c|c|c|c|c|}
\hline Genotypes No & $\begin{array}{c}100 \% \text { irrigation } \\
(\%)\end{array}$ & $\begin{array}{c}50 \% \text { irrigation } \\
(\%)\end{array}$ & $\begin{array}{c}0 \% \text { irrigation } \\
(\%)\end{array}$ & $\begin{array}{l}50 \% \text { irrigation } \\
\text { change by to } \\
\text { control }(\%)\end{array}$ & $\begin{array}{c}\text { 0\% irrigation } \\
\text { change by to } \\
\text { control }(\%)\end{array}$ \\
\hline Mln-4 & 7.12 & 6.85 & 6.33 & -3.79 & -11.10 \\
\hline Mln-20 & 5.77 & 6.71 & 8.48 & 16.29 & 46.97 \\
\hline Mln-23 & 5.42 & 6.11 & 7.55 & 12.73 & 39.30 \\
\hline Mln-27 & 5.41 & 6.13 & 12.20 & 13.31 & 125.51 \\
\hline Mln-28 & 4.94 & 6.54 & 10.25 & 32.39 & 107.49 \\
\hline $\mathrm{Cu}-159$ & 8.56 & 8.55 & 9.58 & -0.12 & 11.92 \\
\hline CU-213 & 6.24 & 5.26 & 5.46 & -15.71 & -12.50 \\
\hline $\mathrm{Cu}-280$ & 7.55 & 8.39 & 9.62 & 11.13 & 27.42 \\
\hline CU-311 & 5.49 & 6.08 & 8.12 & 10.75 & 47.91 \\
\hline Mean & 6.28 & 6.74 & 8.62 & 8.55 & 39.50 \\
\hline $\operatorname{LSD}_{0.05}$ & $\mathrm{~ns}$ & ns & ns & - & - \\
\hline
\end{tabular}

ns = not significantly

The average value of water use efficiency under drought stress $50 \%$ and $0 \%$ irrigation of melon genotypes tested has been 13.71, 19.77 respectively and the mean of control plants has been 12.05 . Increase $50 \%$ and $0 \%$ irrigation indices has occurred as $37.90 \%, 93.85 \%$ respectively according to control of melon genotypes under drought stress (Table 14). Causes and effects of drought and salt stresses, which was basically justifiable by their salt- and water retention ability (Khodadadi Dehkordi, 2017). The average value of total fruit yield under drought stress $50 \%$ and $0 \%$ irrigation of melon genotypes tested has been $13470,16190(\mathrm{~kg} / \mathrm{ha})$ respectively and the mean of control plants has been $14690(\mathrm{~kg} / \mathrm{ha})$ (Table 15). Water stress significantly reduced the fruit yield of the melon plant. Similar results (Srinivas et al., 1989) were obtained from melon and watermelon by Bhella (1985). In our previous study, a decrease in melon fruit yield was seen due to water stress (Kirnak et al., 2005).

Table 14. In the applications of melon genotypes quantities in different $50 \%$ and $0 \%$ irrigation under the normal condition and drought stress condition; water use efficiency quantity of $(\%)$ change by to control

\begin{tabular}{c|c|c|c|c|c}
\hline Genotypes No & $\begin{array}{c}\mathbf{1 0 0 \%} \text { irrigation } \\
(\boldsymbol{\%})\end{array}$ & $\begin{array}{c}\mathbf{5 0 \%} \text { irrigation } \\
\mathbf{( \% )}\end{array}$ & $\begin{array}{c}\mathbf{0 \%} \text { irrigation } \\
\mathbf{( \% )}\end{array}$ & $\begin{array}{c}\mathbf{5 0 \%} \text { irrigation } \\
\text { change by to } \\
\text { control } \mathbf{( \% )}\end{array}$ & $\begin{array}{c}\text { 0\% irrigation } \\
\text { change by to } \\
\text { control }(\boldsymbol{\%})\end{array}$ \\
\hline Mln-4 & $10.85 \mathrm{~d}$ & $9.61 \mathrm{f}$ & $8.16 \mathrm{~g}$ & -10.32 & -25.70 \\
Mln-20 & $9.89 \mathrm{~d}$ & $17.78 \mathrm{~b}$ & $26.38 \mathrm{a}$ & 79.76 & 156.58 \\
Mln-23 & $14.96 \mathrm{~b}$ & $17.70 \mathrm{~b}$ & $21.55 \mathrm{~d}$ & 18.34 & 41.79 \\
Mln-27 & $9.77 \mathrm{~d}$ & $18.30 \mathrm{a}$ & $24.95 \mathrm{~b}$ & 87.89 & 156.95 \\
Mln-28 & $7.88 \mathrm{e}$ & $11.35 \mathrm{e}$ & $23.19 \mathrm{c}$ & 43.18 & 192.79 \\
Cu-159 & $13.65 \mathrm{c}$ & $14.16 \mathrm{c}$ & $19.23 \mathrm{e}$ & 9.67 & 31.60 \\
$\mathrm{CU}-213$ & $29.12 \mathrm{a}$ & $11.62 \mathrm{e}$ & $21.46 \mathrm{~d}$ & -61.54 & -31.09 \\
Cu-280 & $7.35 \mathrm{e}$ & $13.34 \mathrm{~d}$ & $18.28 \mathrm{e}$ & 81.28 & 137.25 \\
CU-311 & $4.94 \mathrm{f}$ & $9.56 \mathrm{f}$ & $14.77 \mathrm{f}$ & 92.83 & 184.50 \\
\hline Mean & 12.05 & 13.71 & 19.77 & 37.90 & 93.85 \\
LSD 0.05 & $\mathrm{~ns}$ & 0.30 & 1.17 & - & - \\
\hline
\end{tabular}

ns = not significantly 
Table 15. In the applications of melon genotypes quantities in different $50 \%$ and $0 \%$ irrigation under the normalcondition and drought stress condition; Total fruit yield quantity of $(\%)$ change by to control

\begin{tabular}{|c|c|c|c|c|c|}
\hline Genotypes No & $\begin{array}{c}100 \% \text { irrigation } \\
(\mathrm{kg} / \mathrm{ha})\end{array}$ & $\begin{array}{l}50 \% \text { irrigation } \\
(\mathrm{kg} / \mathrm{ha})\end{array}$ & $\begin{array}{c}0 \% \text { irrigation } \\
(\mathrm{kg} / \mathrm{ha})\end{array}$ & $\begin{array}{l}50 \% \text { irrigation } \\
\text { change by to } \\
\text { control (\%) }\end{array}$ & $\begin{array}{c}0 \% \text { irrigation } \\
\text { change by to } \\
\text { control }(\%)\end{array}$ \\
\hline Mln-4 & $13080 \mathrm{c}$ & $9680 \mathrm{e}$ & 6550 & -25.99 & -49.92 \\
\hline Mln-20 & $11780 \mathrm{~d}$ & $18070 \mathrm{ab}$ & 20890 & 53.40 & 77.33 \\
\hline Mln-23 & $16900 \mathrm{~b}$ & $17220 \mathrm{~b}$ & 18030 & 1.89 & 6.69 \\
\hline Mln-27 & $11550 \mathrm{~d}$ & $18350 \mathrm{a}$ & 20930 & 58.87 & 81.21 \\
\hline Mln-28 & $9000 \mathrm{e}$ & $12340 \mathrm{~d}$ & 18720 & 37.11 & 108.00 \\
\hline $\mathrm{Cu}-159$ & $15770 \mathrm{~b}$ & $13380 \mathrm{c}$ & 15660 & -15.16 & -0.70 \\
\hline CU-213 & $34570 \mathrm{a}$ & $11700 \mathrm{~d}$ & 17720 & -66.16 & -48.74 \\
\hline $\mathrm{Cu}-280$ & $8440 \mathrm{e}$ & $13320 \mathrm{c}$ & 14710 & 57.82 & 74.29 \\
\hline CU-311 & $5790 \mathrm{f}$ & $9590 \mathrm{e}$ & 12460 & 65.63 & 115.20 \\
\hline Mean & 14100 & 1374 & 16190 & - & - \\
\hline $\operatorname{LSD}_{0.05}$ & 115.29 & 92.85 & $\mathrm{~ns}$ & - & - \\
\hline
\end{tabular}

$\mathrm{ns}=$ not significantly

The best performers in terms of water use efficiency and total fruit yield have been selected by taking into account the $\%$ change quantities $50 \%$ and $0 \%$ irrigation of the melon genotypes in the experiment in comparison to their control in drought stress application. These genotypes are respectively; Mln27 and Mln 28 (Tables 14, 15).The ranking of genotypes is shown in the Table 16. Classification of the 9 melon genotypes for their drought responses to tolerant, mild tolerant, susceptible in this Table 17.

Table 16. The experiment melon genotypes grown under irrigation 50\% and $0 \%$ compared to the control parameters are recorded and measured changes in Physiological quantities weighted rating process is done, the highest score genotipten until the lowest point genotipe

\begin{tabular}{c|c}
\hline Genotype No & Weighted Rating \\
\hline Mln-28 & 5343 \\
CU-311 & 4526 \\
Mln-27 & 4519 \\
Mln-20 & 4321 \\
Cu-280 & 3029 \\
Mln-23 & -19 \\
Cu-159 & -956 \\
Mln-4 & -2452 \\
CU-213 & -3397 \\
\hline
\end{tabular}

Table 17. Classification of the 9 melon genotypes for their drought responses

\begin{tabular}{c|c|c}
\hline Tolerant & Mild Tolerant & Susceptible \\
\hline CU-311 & Mln-23 & Mln-4 \\
Mln-28 & Cu-159 & CU-213 \\
Mln-27 & & \\
Mln-20 & & \\
Cu-280 & & \\
\hline
\end{tabular}




\section{Conclusion}

After that, our ongoing studies will be included that Mln 28 and CU 311 genotypes which are the most tolerant selected for the second times repeating of "drought stress performance in the field" and the most suitable for commercial improving by doing the selection of melon genotypes, and an evidence variety. The need for reinforcing the tolerance levels of genotypes in drought stress conditions will be more apparent after the second re-experiment by the prominence of hopeful lines.

Acknowledgements. This study was made possible through a part of TUBITAK- KAMAG 109 G099 No 'F1 TURKEY Vegetable Varieties and Qualified Line Development Project.

\section{REFERENCES}

[1] Anyia, A. O., Herzog, H. (2004): Genotypic variability in drought performance and recovery in cowpea under controlled environment. - J. Agron. Crop Sci. 190: 151-159.

[2] Ashraf, M., Oleary, J. W. (1996): Effect of drought stress on growth, water relations, and gas exchange of two lines of sunflower differingin degree of salt tolerance. - Int. J. Plant Sci. 157(6): 729-732.

[3] Ashraf, M., Ashfaq, M., Ashraf, M. Y. (2002): Effects of increasedsupply of potassium on growth andnutrient content in pearl millet under water stress. - Biologia Plantarum 45: 141-144.

[4] Askari, A., Ardakani, M. R., Vazan, S., Paknejad, F., Hosseini, Y. (2017): The effect of mycorrhizal symbiosis and seed priming on the amount of chlorophyll index and absorption of nutrients under drought stress in sesame plant under field conditions. Applied ecology and environmental research 16(1): 335-357.

[5] Azevedo, N. A., Prisco, J. T., Filho, J. E., Lacerda, C. F., Silva, J. V., Costa, P. H., Filho, E. G. (2004): Effects of salt stress on plant growth, stomatal response and solute accumulation of different maize genotypes. - Braz. J. Plant Physiol. 16(1): 31-38.

[6] Bewley, J. D. (1979): Physiological aspects of desiccation tolerance. - Annu Rev Plant Physiol 30: 195-238.

[7] Bhella, H. S. (1985): Muskmelon growth. Yield and nutrient as influenced by planting method and trickle irrigation. - J Am Soc Hortic Sci 110: 793-796.

[8] Blum, A., Ebercon, A. (1981): Cell membrane stability as a measure of drought and heat tolerance in wheat. - Crop Sci 21: 43-47.

[9] Boyer, J. S. (1982): Plant productivity and environment. - Science 218: 443-448.

[10] Bray, E. A., Bailey-Serres, J., Weretilnyk, E. (2000): Responses to abiotic stresses. - In: Gruissem, W., Buchannan, B., Jones, R. (eds.) Biochemistry and molecular biology of plants. American Society of Plant Physiologists, Rockville, MD, pp 1158-1249.

[11] Cachorro, P., Ortiz, A., Cerda, A. (1994): Implications of calcium on theresponse of Phaseolus vulgaris L. to salinity. - Plant and Soil 159: 205-212.

[12] Chaves, M. M., Pereira, J. S., Maroco, J., Rodrigues, M. L., Ricardo, C. P. P., Osorio, M. L., Carvalho, I., Faria, T., Pinheiro, C. (2002): How plants cope with water stress in the field, Photosynthesis and Growth. - Annals of Botany 89: 907-916.

[13] Clarke, N., Hetschkun, H., Jones, C., Boswell, E., Marfaing, H. (1993): Identification of stress tolerance traits in sugar beet. - In: Jackson, M. B., Black, C. R. (eds.) Interacting Stress on Plants in a Changing Climate. Springer-Verlag, Berlin, pp. 511-524.

[14] Dadkhah, A. R. (2010): Effect of long term salt stress on gas exchange and leaf carbohydquantity contents in two sugar beet (Beta vulgaris L.) cultivars. - Res. J. Biol. Sci. 5(8): 512-516. 
[15] Dexter, S. T. (1956): Evaluation of crop plants for winter hardiness. - Adv Agron 8: $203-$ 209.

[16] Dlugokecka, E., Kacperska-Palacz, A. (1978): Re-examination of electrical conductivity method for estimation of drought in-jury. - Biologia Plantarum (Prague) 20: 262-267.

[17] Echevarria-Zomeno, S., Arıza, D., Jorge, I., Lenz, C., Jesusvjorrı, N. A., Navarro, R. (2009): Changes in the protein profile of Quercus 1lex leaves in response to drought stress and recovery. - J. Plant Physiol. 166: 233-245.

[18] Fabeiro, C., de Santa Olalla, F. M., de Juan, J. A. (2002): Production of muskmelon (Cucumis melo L.) under controlled deficit irrigation in a semi-arid climate. - Agric Water Manag 54: 93-105.

[19] Fahad, S., Bajwa, A. A., Nazir, U., Anjum, S. A., Farooq, A., Zohaib, A., Sadia, S., Nasim, W., Adkins, S., Saud, S., Ihsan, M. Z., Alharby, H., Wu, C., Wang, D., Huang, J. L. (2017): Crop production under drought and heat stress: plant responses and management options. - Front. Plant Sci. 8: 1147. 10.3389/fpls.01147.

[20] Fan, S., Blake, T. G. (1994): Absisic acid induced electrolyte leakage in woody spe-cies with contrasting ecological require-ments. - Plant Physiol. 89: 817-823.

[21] Grzesiak, M. T., Grzesiak, S., Skoczowski, A. (2006): Changes of leaf water potential and gas exchange during and after drought in triticale and maize genotypes differing in drought tolerance. - Photosynthetica 44(4): 561-568.

[22] Gunay, A. (2005): Special Vegetable Growing. - Chapter, Tomato Breeding: 318-343.

[23] Halim, R. A., Buxton, D. R., Hattendorf, M. J., Carlson, R. E. (1990): Crop water stress index and forage quality relationships in alfalfa. - Agric. J. 82: 906-909.

[24] Khodadadi Dehkordi, D. (2017): Effect of superabsorbent polymer on salt and drought resistance of eucalyptus globules. - Applied ecology and environmental research 15(4): 1791-1802.

[25] Kirnak, H., Higgs, D., Kaya, C., Tas, I. (2005): Effects of irrigation and nitrogen quantitys on growth, yield, and quality of muskmelon in semiarid regions. - Journal of Plant Nutrition 28: 621-638.

[26] Knight, S. L., Rogers, R. B., Smith, M. A. L., Spomer, L. A. (1997): Effects of NaCl salinity on miniature dwarf tomato 'Micro-Tom': I. Growth analyses and nutrient composition. - Journal of Plant Nutrition15: 2315-2327.

[27] Kusvuran, S., Dasgan Y. H., Abak, K. (2011): Responses of different melon genotypes to drought stress. - Yuzuncu Yil University Journal of Agricultural Sciences 21: 209-219.

[28] Leopold, A. C., Willing, R. P. (1983): Evidence of toxicity effects of salt on membranes. - In: Staples, R. C., Toenniessen, G. H. (eds.) Plant improvement for irrigated crop production under increasing saline conditions. John Wiley and Sons, New York, pp 678685.

[29] Lester, G. E., Oebker, N. F., Coons, J. (1994): Preharvest furrow and drip irrigation schedule effects on postharvest muskmelon quality. Postharvest Biol Thechnol 4: 57-63.

[30] Levitt, J. (1972): Responses of Plants to Environmental Stresses. - Academic Press, New York.

[31] Mafakheri, A. (2010): Effect of drought stress on yield, proline and chlorophyll contents in three chickpea cultivars. - Aust. J. Crop Sci. 4(8): 580-585.

[32] Matthews, M. A., Boyer, J. S. (1984): Acclimation of photosynthesis to low water potentials. - Plant Physiol. 74: 161-166.

[33] Mengel, K., Kirkby, E. A. (1987): Principles of Plant Nutrition. - Dordrecht, the Netherlands: KluwerAcademic.

[34] Mohammadian, R., Khoyi, F. R., Rahimian Moghaddam, H. M, Ghassemi Golezani, K., Sadeghian, S. Y. (2001): The effects of early season drought on stomatal conductance, leaf-air temperature difference and proline accumulation in sugar beet genotypes. - J. Agric. Sci. Technol. 3: 181-192. 
[35] Serrano, R., Mulet, J. M., Rios, G., Marquez, J. A., de Larrinoa, I. F., Leube, M. P., Mendizabal, I., Pascual-Ahuir, A., Proft, M., Ros, R., Montesinos, C. (1999): A glimpse of the mechanisms of ion homeostasis during salt stress. - J Exp Bot 50: 1023-1036.

[36] Shmueli, M., Golsberg, D. (1971): Sprinkler, furrow and trickle irrigation of muskmelon in an arid zone. - HortScience 6: 557-559.

[37] Silva, E. N., Ribeiro, R. V., Silva, S. L.,Viegas, R. A., Silveire, J. A. (2011): Salt stress induced damages on the photosynthesis of physic nut young plants. - Sci. Agric. 68(1): $62-68$.

[38] Srinivas, K., Hedge, D. M., Havanagi, G. V. (1989): Plant water relations, canopy temperature, yield and water-use efficiency of watermelon Citrullus lanatus (Thunb.) Matsum et Nakai under drip and furrow irrigation. - Journal of Horticultural Science 64: 115-124.

[39] Tiwari, S., Puneet, C. L., Chandra, S. C., Nautiyal, S. (2016): Pseudomonas putida attunes morphophysiological: biochemicaland molecular responses in Cicer arietinum L. during drought stress and recovery. - Plant Physiol. Biochem. 99: 108-117.

[40] Turner, N. C., Begg, J. E., Tonnet, M. L. (1998): Osmotic adjustment of sorghum and sunflower crops in response to water deficits and its influence on the water potential at which stomta close. - Aust. J. Plant Physiol. 5(5): 597-608.

[41] Wang, W. X., Vinocur, B., Shoseyov, O., Altman, A. (2001): Biotechnology of plant osmotic stress tolerance. physiological and molecular considerations. - Acta Hort 560: 285-292.

[42] Wang, W. X., Vinocur, B., Altman, A. (2003): Plant responses to drought, salinity and extreme temperatures: towards genetic engineering for stress tolerance. - Planta 218: 114.

[43] Xu, Z., Zhou, G. (2008): Responses of leaf stomatal density to water status and its relationship with photosynthesis in a grass. - J. Exp. Bot. 59(12): 3317-3325.

[44] Zahoor, R., Dong, H., Abid, M., Zhao, W., Wang, Y., Zhou, Z. (2017): Potassium fertilizer improves drought stress alleviation potential in cotton by enhancing photosynthesis and carbohydrate metabolism. - Environmental and Experimental Botany 137: 73-83.

[45] Zhou, R., Yu, X., Ottosen, C., Rosenqvist, E., Zhao, L., Wang, Y., Yu, W., Zhao, T., Wu, Z. (2017): Drought stress had a predominant effect over heat stress on three tomato cultivars subjected to combined stress. - BMC Plant Biology 17: 24.

[46] Zhu, J. K. (2001): Plant salt tolerance. - Trends Plant Sci 6: 66-71. 